\title{
The use of the Internet for the development of value orientations of Russian students in heuristic cognitive activity: problems and solutions
}

\author{
Galina V. Makotrova, Valentina E. Musina* and Olga $A$. Moiseenko \\ Belgorod State University, Pobeda St. 85, 308015 Belgorod, Russia
}

\begin{abstract}
The purpose of the article is to consider of the possibilities of using the Internet in the development of value orientations of Russian students in the course of heuristic cognitive activity. When polling a representative sample of students with a creative level of development of the research potential, we found that in heuristic cognitive activity when using the Internet, students are primarily attracted by unusual facts (45\%), the ability to speculate about the meaning of certain concepts, statements and effects ( $34 \%)$. A survey of a general sample of high school students $(\mathrm{N}=$ 2095) during a formative experiment with the participation of students in grades 8-11 revealed a wide range of problems of realization of value orientations and meanings of students in cognitive activity of students. These are the opportunities to study various theories on the Internet, problems in the implementation of value orientations and the meanings of the cognitive activity of students: from the possibility of studying various theories on the Internet and using them to explain incomprehensible phenomena, processes. Only $18 \%$ of students are always satisfied with the possibilities of the Internet in the heuristic cognitive activity of students, $43 \%$ of respondents are often satisfied, sometimes $34 \%$ of high school students; $5 \%$ of respondents are completely dissatisfied.
\end{abstract}

\section{Introduction}

In modern school education, special attention is paining to compensation for losses that have appeared when using the Internet in traditional education, which leads to the concern of scientists and practitioners with the problem of personality development, its value orientations in search cognitive activity. They are primarily associated with the presence of thoughtless copying of information by students, with a violation of the optimal ratio of heuristic and reproductive cognitive activity.

Pedagogical research shows that the Internet can be productively using in the practice of teaching students to formulate research problems and tasks [2, 4], organize reflexive activity in understanding the importance of cognitive products, understanding the goals and values

\footnotetext{
*Corresponding author: musina@bsu.edu.ru
} 
of research $[1,2]$. The ways of organizing the choice of technological elements of research [9], construction and implementation of search strategies [10] are known.

At the same time, the studies expressed concern about the low level of awareness of the educational potential of digital media by students, despite the high level of technological competence of students in their use (N. Selwyn, O. Hussein) [8]. Teachers are also alarmed by the low level of criticality to the information used and time management skills, reduced memory and concentration of attention on the problem (K. Purcell, L. Rainier, A. Heaps, J. Buchanan, L. Friedrich, etc.) [7].

The introduction in Russia of new educational standards in school education in Russia draws the attention of teachers to assessing the values and meanings of students, developing ways of developing value orientations of schoolchildren in heuristic (search) cognitive activity in the context of using the Internet [5]. This orientation of researchers is not accidental. It is shown that the dominance of values-goals in the system of value orientations of trainees' activity (values-means, values-relationships, values-qualities, values-knowledge) provides a justification for the choice of other values [3].

\section{Research methodology and methods}

The implementation of the anthropological approach provided a focus of scientific attention in solving the problem of the development of value orientations of Russian students in heuristic cognitive activity on the tendency of information and communication support of freedom of choice in obtaining new knowledge by students. The use of a culturological approach made it possible to develop criteria for the research potential of students, implemented in heuristic cognitive activity. By the research potential of students, we mean a dynamic personal resource conditioned by the inclinations, abilities, experience of learning in learning and life, representing the integrative unity of the student's orientation towards knowing oneself, other people and the world; sensually visual images and knowledge about the universe, wildlife, society and man; ways of knowing the world around. In the course of solving research problems, he provides personal self-determination, restructuring of the direction and content of cognitive activity, creative self-development. The criteria for the research potential of students (ISP) include motivation for research, creative activity, technological readiness to search, scientific style of thinking. Assessment of its development on a 4-point scale made it possible to identify the following levels of development: adaptive, reproductive, heuristic and creative.

Computer diagnostics of indicators of the research orientation of high school students in their future professional activities, indicators of the research potential of students on a fourpoint scale made it possible to identify a number of problems of using the Internet in the development of value's orientations of students in cognitive activity.

Carrying out a correlation analysis according to K. Pearson according to the data of the formative experiment made it possible to substantiate the didactic pattern of using the Internet within the framework of the ongoing trend of information and communication support for freedom of choice in obtaining new knowledge. The method of ranks made it possible to identify the most significant priorities of schoolchildren with heuristic and creative (highest) levels of development of their research potential in using the Internet.

\section{Results}

In determining the values and meanings of the research activities of students, we relied primarily on the manifestations of students' motivation for research, as well as on the indicators of their orientation towards research in the future profession, their relationship 
with indicators of the research potential of the individual. We analyzed the values and meanings of using the Internet in heuristic cognitive activity, a representative sample of 116 high school students with the highest (creative) level of development of their research potential from 14 educational institutions.

In addition, we studied the manifestation of the orientation of students towards research in their future profession-using computer testing of 2095 high school students with different levels of development of their research potential.

The preferences of students with a creative level of development of the research potential of heuristic cognitive activity using the Internet has revealed shown in Table 1.

Table 1. Preferences of students with a creative level of development of research potential in heuristic cognitive activity using the Internet.

\begin{tabular}{|c|c|}
\hline $\begin{array}{c}\text { What attracts students with a creative level of development of research } \\
\text { potential in heuristic cognitive activity using the Internet Number of } \\
\text { schoolchildren (\%) }\end{array}$ & $\begin{array}{c}\text { Number of } \\
\text { students } \\
(\%)\end{array}$ \\
\hline Unusual Facts & 45 \\
\hline The ability to speculate on the meaning of certain statements, effects & 34 \\
\hline Ability to find different ways to solve the same problem & 34 \\
\hline Situations in which the teacher helps to think, but does not do it instead & 31 \\
\hline An opportunity to search for connections between phenomena & 25 \\
\hline External effect of experiment & 15 \\
\hline Sufficient time to solve problem & 8 \\
\hline Opportunity to find help from friends in times of difficulty & 8 \\
\hline The opportunity to spend more time solving a problem that was not \\
immediately resolved 8
\end{tabular}

At the same time, our survey showed the existence of the problem of the development of values and meanings of students using the Internet in heuristic cognitive activity. Thus, in a learning environment, often or very often only $46 \%$ of high school students with the highest level of research potential use the Internet to predict the outcome of a task. For $10 \%$ of the respondents, teachers, as a rule, do not offer to search for meaning in systematic, systematic work under any circumstances. When assessing the solution obtained, $38 \%$ of the respondents evaluate the solution obtained independently, 39\% of students use the algorithm proposed by the teacher, and $24 \%$ of the respondents rely on the algorithm and the teacher's questions.

The attitude of schoolchildren to the presented opportunities to study various theories and, with their help, explain incomprehensible phenomena, processes, facts, is also alarming. When such proposals are implementing, $18 \%$ of the general sample are always satisfied, often $43 \%$ of the respondents, only sometimes and $34 \%$ of the senior students. Five $\%$ of the respondents say that they do not like doing this at all.

A survey of students in a general sample also showed that distance preparation of high school students for various kinds of competitions with the participation of university teachers are realized only in $7 \%$ of students. Add that $38 \%$ of high school students express a desire to study the technology of scientific research under the guidance of scientists using remote technologies, 38\% would not mind getting to know it. Besides $36 \%$ of students from the general sample definitely strive for studies in correspondence schools of universities with a 
high scientific potential, material, and technical base; answer that $34 \%$ of the respondents would most likely have studied it upon receipt of such proposals.

Within the framework of the trend of information and communication support of freedom of choice in obtaining new knowledge by students, which was currentlyy being implemented in school education in Russia, we identified the pattern of using digital means, including the Internet, in the heuristic cognitive activity of schoolchildren. Its content is as follows: immersion of students in a digital problem-situational space, in which scientific, professional activities and life realities are presented, leads to the formulation of problems and tasks, awareness of the value of research, construction and implementation of a search strategy. It was being successfully implemented in the context of a formative experiment to develop the research potential of schoolchildren in grades 8-11 [6].

Calculated K. Pearson's coefficients at the level of significance $\mathrm{p}=0.01 ; \mathrm{r}>0.254$ for $\mathrm{n}=$ 100 revealed a relationship between the frequency of using the Internet in educational work and the desire of students to use its resources to obtain new cognitive information. We were particularly interested in a number of answers from schoolchildren with creative and heuristic levels of development of research potential $(n=135)$ in the course of completing tasks for a popular science text, in which they explain their interest in their choice of text on the Internet. The choice of text among students is primarily associated with interest in the subject $(73 \%)$, with the practical orientation of the selected problem (51\%), with interest in a section of the scientific field (43\%), with the opportunity to think about the problem $(40 \%)$, with interest to the unusual content presented in the text (33\%). Less often, the choice of text is associated with the possibility of getting an answer to a specific question (21\%); the ability to critically comprehend the stated problem (13\%), the amount of data (with a small amount of unknown data in $8 \%$ of subjects, with a large amount of unknown data in $18 \%$ ).

In the experimental conditions of working with the text, students of grades 8-11 were able, first of all, to develop a definite position when analyzing various hypotheses (58\%), to understand that various considerations can be used in the study: technical feasibility, ecological aspect, political and religious considerations, etc. (58\%), gain experience in critical analysis of different views (42\%). At the same time, an insignificant number of subjects see sense in the awareness of the drama and the attractiveness of scientific research in the conditions of educational research $(21 \%$ from the group of schoolchildren with a heuristic level of research experience and $18 \%$ from the group with a creative level of research experience).

The revealed regularity, show, that the immersion of a student in a digital problemsituational space, in which scientific, professional activities and life realities are presented. In addition, leads to the formulation of problems and tasks, an awareness of the value of research, the construction and implementation of search strategies, provided the development of the following didactic principles of using digital means in the development of the research potential of schoolchildren: value-semantic attitude, priority of creative initiative, openness of content.

The implementation of the principle of value-semantic relations means providing students with the opportunity to quickly express emotions using the Internet's capabilities, determine the values and meanings of the educational (scientific) search process, and evaluate the results of research. For this, the teacher can use software tools, with the help of which schoolchildren quickly build a system of values-goals, values-means of achieving them, comprehend the emotional attitude to a number of cognitive actions, to the results of activities, reveal their attitude to the barriers that have arisen in obtaining new knowledge (personal, informational, intellectual). Schoolchildren can mark electronic text, make associative rows, chains of keywords that reflect their value-semantic relationship to the text, select quotes for texts, highlight the data that is necessary first. Using ready-made images, texts representing scientific, professional activities, life situations, under the guidance of a 
teacher, students can compose many assignments on a specific topic, a section that aroused their maximum interest, which can then be selecting to work on them in the lesson, in extracurricular activities or in homework conditions.

The principle of creative initiative involves supporting the creative activity of students when using digital technologies of the Internet: unfinished, fragmentary, interdisciplinary texts, and video materials in teaching, for which analogs of scientific, professional activity and life realities can be founding. Having made the choice of the text, video material, the students are formulated questions for it; make up tasks research topics, initiative proposals in the forms of cooperation. Used, in the search for answers and solutions by building logical chains of keywords to search for information on the Internet and complement the list of sites provided, for $g$ virtual experiments, participate in determining the criteria and indicators for evaluating search results. When using modern software systems, digital laboratories, students have the opportunity to modify cognitive issues, build and improve search strategies, and illustrate research results.

The principle of openness of content requires arming students with strategies, technologies and methods of working with a variety of digital information, which represents scientific, professional activities and life realities. Students use digital technologies to organize information, to build diagrams of what they read, to present them in a visual form in the form of mind maps, to conduct critical analysis. With the help of Internet technologies (for example, using the Google Docs service). Students supplement web quests in which a list of sites for solving a specific problem is presented, joint dictionaries, reference books are created, texts in which information on a specific problem is concisely presented, and productive exchange is carried out reading results, comments on written or written in real time texts.

The use of strategies for searching information on the Internet ensures faster assimilation by students of the conceptual apparatus of the problem under study, prompt receipt of answers to an information request, and the formulation of new tasks and problems. In addition, the transformation of information into a special object for observation in the context of analyzing the relationship between the past and the present, tracking the influence of information on future research, identifying the reasons for the violation of the relationship between the past and the present, solving research problems associated with the modification of information. Mastering the technologies and methods of working with digital information also gives students the opportunity to organize their knowledge, query various databases, improve their skills in working with documents in a research environment, make predictions, and propose solutions to current problems.

\section{Discussion}

The obtained results of the survey of schoolchildren draw the attention of researchers to the values and meanings of the search activity of students realized in teaching, and make it possible to formulate new problems of scientific research. The revealed regularity deepens didactic knowledge about the use of the Internet in student-centered learning. The developed didactic principles, which, by means of the Internet, provide the development of value orientations of schoolchildren in heuristic cognitive activity, create conditions for obtaining new approaches and practices for developing the research potential of schoolchildren, increasing the effectiveness of learning.

Findings. In the process of theoretical and experimental research, the following conclusions were obtained:

1. In heuristic cognitive activity when using the Internet, students are primarily attracted by unusual facts $(45 \%)$, the ability to speculate on the meaning of certain statements, effects $(34 \%)$. 
2. A survey of a general sample of high school students showed that there is a problem of values and meanings of students development with the help of the Internet the in the search of cognitive activity: of the opportunity to study various theories and with their to explain incomprehensible phenomena, processes, facts. $34 \%$ of high school students are satisfied of the Internet abilities and 5\% of respondents do not feel pleasure.

3. The relationship was founding between the immersion of school students in the digital problem-situational space of the Internet, in which scientific, professional activities, life realities are presenting, and the formulation of problems and tasks by them, awareness of the value of research, construction and implementation of search strategies.

4. Adherence to the didactic principles of using digital means, including the Internet, in the development of the research potential of schoolchildren (value-semantic attitude, priority of creative initiative, openness of content) ensures the development of value orientations of schoolchildren.

5. The results obtained create conditions for the emergence of new approaches and practices for the development of values and meanings in the process of teaching schoolchildren using the Internet.

\section{References}

1. S. Bubb, M.A. Jones, Learning from the COVID-19 home-schooling experience: Listening to pupils, parents/carers and teachers, Improving Schools, 209-222 23(3) (2021). Retrieved from: https://journals.sagepub.com/doi/full/10.1177/1365480220958797

2. R. Daoud, L. Starkey, E. Eppel, T.D. Vo, \& A. Sylvester The educational value of internet use in the home for schoolchildren: A systematic review of literature, Journal of Research on Technology in Education. (2020). DOI:10.1080/15391523.2020.1783402

3. I. F. Isaev, G. V. Makotrova, Educational and research culture as a factor of creative self-development of a high school student in profile training: monograph, BelSU Publishing House, Belgorod, 236 (2007).

4. Lu Han, Problems and Solutions of the Integration and Development of Internet + and Modern Education, New Curriculum Research 84-86, 11 (2019). Retrieved from: https://kns.cnki.net/KCMS/detail/detail.aspx? dbcode $=$ CJFD\&filename $=$ XKCY201911035

5. G. V. Makotrova, Projecting electronic textbooks for research training of schoolchildren, Otechestvennaya i zarubezhnaya pedagogika, 58-74 1(74) (2021) Retrieved from: https://www.elibrary.ru/download/elibrary_44792588_56381204.pdf

6. G. V. Makotrova, The Internet network in the Development of Scientific skills of Students: a cultural approach, FLINTA, Moscow, (2014), Retrieved from: https://rucont.ru/efd/246547

7. K. Purcell, L. Rainie, A. Heaps, J. Buchanan, L. Friedrich, A. Jjacklin, C. Chen and C. Zickuhr, How Teens Do Research in the Digital World. Pew Research Center's Internet \& American Life Project, 1615 L St., NW, Washington, D.C. 20036, 2012. Retrieved from: http://pewinternet.org/Reports/2012/Student-Research

8. N. Selwyn, O. Husen, The educational benefits of technological competence: an investigation of students' perceptions, Evaluation \& Research in Education, 137-141, 23(2) (2010). Retrieved from: https://eric.ed.gov/?id=EJ886090

9. G. Singh \& G. Datt, ICT in open and distance education: a tool for learner support services and policy development, Humanities \& Social Sciences Reviews, 275-284, 8(5) (2020). DOI: https://doi.org/10.18510/hssr.2020.8525

10. P.J. Williams, N. Nguyen, J. Mangan, Using technology to support science inquiry learning, Technology and Science Education, 26-57, 7(1) (2017) 